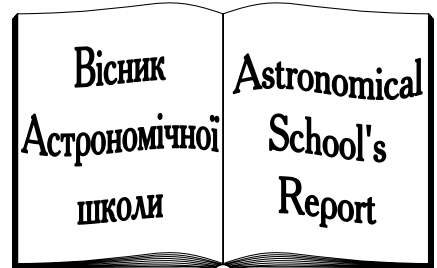

ISSN 2411-6602 (Online)

ISSN 1607-2855 (Print)

Volume $12 \bullet$ Issue $2 \bullet 2016 \quad$ P. $122-124$

UDC 523.4

\title{
Dynamics of the asteroid rings (10199) Chariklo
}

\author{
V.V. Troianskyi*, O.A. Bazyey
}

Astronomical Observatory, Odessa National University

In 2014 it was reported on opening two rings around asteroid (10199) Chariklo (Braga-Ribas F., et al., 2014, Nature, 508, 72-75) and it became the fifth object of the Solar system known to have ring system, after Jupiter, Saturn, Uranus and Neptune. The main component of the system is the biggest Centaur. This work considers the erosion time of rings in the asteroid system (10199) Chariklo, that is due to a number of effects. Also, we have calculated the mass and period of rotation of the asteroid's shepherd satellite.

ДИНАМІКА КІЛЕЦЬ АСТЕРОЇДА (10199) СНАRIКLО, Троянський В.В., Базєй О.А. - У 2014 році було повідомлено (Braga-Ribas F., et al., 2014, Nature, 508, 72-75) про відкриттл двох кілець навколо астероїда (10199) Chariklo; він став п'ятим об'єктом Сонячної системи, у якого виявлено система кілець, після Юпітера, Сатурна, Урана і Нептуна. Головний компонент системи є найбільшим Кентавром. У роботі розглянуто час ерозії кілець в астероїдній системі (10199) Chariklo, що відбувається через низку ефектів. Також ми визначили масу i період обертання передбачуваного супутника-пастуха даного астероїда.

ДИНАМИКА КОЛЕЦ АСТЕРОИДА (10199) СНАRIКLО, Троянский В.В., Базей А.А. - В 2014 году сообщалось (Braga-Ribas F., et al., 2014, Nature, 508, 72-75) об открытии двух колеи вокруг астероида (10199) Chariklo; он стал пятым объектом Солнечной системы у которого обнаружена система колеи, после Юпитера, Сатурна, Урана и Нептуна. Главный компонент системы является самым крупным Кентавром. В работе рассмотрено время эрозии колеи в астероидной системе (10199) Chariklo, которая происходит из-за ряда эффектов. Также мы определили массу и период обращения предполагаемого спутника-пастуха данного астероида.

Ключевые слова: астероиды; спутник Chariklo; кольца астероида; спутник-пастух.

Key words: asteroids; satellites Chariklo; rings asteroid; shepherd satellite.

\section{THE ORBITAL CHARACTERISTICS OF THE ASTEROID SYSTEM (10199) CHARIKLO}

Orbit of (10199) Chariklo located between the orbits of Saturn and Uranus. Its aphelion distance is greater than the perihelion distance of Uranus. Asteroid system rotates in resonance 4:3 (62.53:83.53 years) with Uranus. Table 1 summarizes the Keplerian orbital elements of asteroid system.

Table 1. Orbital data, primary asteroid (Keplerian osculating orbital elements [9]) and other data

\begin{tabular}{|l|c|}
\hline Semimajor axis & $15.754190 \mathrm{AU}$ \\
\hline Eccentricity & 0.1715941 \\
\hline Inclination & $23.411663^{\circ}$ \\
\hline Argument of perihelion & $241.60058^{\circ}$ \\
\hline Ascending node & $300.379814^{\circ}$ \\
\hline Mean anomaly & $60.13111^{\circ}$ \\
\hline Epoch & 2014 May 23 \\
\hline Diameter & $248000 \pm 18000 \mathrm{~m}[4]$ \\
\hline Rotation period & 7.004 hour $[7]$ \\
\hline
\end{tabular}

The asteroid is surrounded by two narrow rings C1R and C2R width of 6600 and 3800 meters with an optical density of 0.38 and 0.06 respectively. The radius of the rings is $390600 \pm 3300 \mathrm{~m}$ and $404,800 \pm 3,300 \mathrm{~m}$, respectively. Opened jointly by European and American astronomers in 2013 during occultation of the star UCAC4 248-108672 [2]. After the discovery a lot of other observations of this object were carried out resulting in the clarification of parameters of the system [1]. Possibility of rings disintegration as a result of the tidal effect from the planets of the Solar system [8] in the 1 million years' time interval is also considered.

\section{THE CHARACTERISTIC TIME OF EROSION OF THE RINGS}

Narrow and eccentric rings should be disintegrated as a result of erosion for the time much less then age of the Solar system. The fact that these rings be observed means that we live in a special epoch when such rings exist, or implies the existence of some retention mechanism that retains the properties of the rings unchanged over long periods.

*Volodymyr Troianskyi; $\bigotimes$ v.troianskyi@onu.edu.ua 
Let us consider the time of rings life, i.e. erosion of narrow rings not retained by any forces, due to a number of effects: the mutual collisions of particles of the ring, the Poynting-Robertson effect and differential precession. A detailed derivation of formulas for the erosion of the rings, considered by Murray and Dermot [3]. In the Braga-Ribas et al. [2] calculated the time of the asteroid rings erosion due to particle collisions and the Poynting-Robertson effect. We calculate the erosion time due to the third effect differential precession of the rings.

Compression of the central asteroid causes that elongated orbits of rings particles to precess at a speeds of approximately described by the equation [3]

$$
\dot{\varpi} \approx 3 \pi J_{2}\left(\frac{R_{A}}{a_{S t}}\right)^{2} T,
$$

where the $J_{2}$ - the second zonal harmonic $(0.014 \pm 0.002)$, calculated by you on the previously proposed algorithm [6], $R_{A}$ - radius of the asteroid, $a_{S t}-$ semi-major axis of the orbit $(400300 \pm 9700 \mathrm{~m})$, the alleged shepherd satellite, $T$ - period of rotation ( 0.74 days and 0.78 days).

The difference between the values for the inner and outer edges of the eccentric rings (radial width of the ring along the major axis of its orbit are different) in semi-major axis is given by formula [3]

$$
\delta \dot{\varpi} \approx-\frac{7}{2} \dot{\varpi} \frac{W}{a_{S t}},
$$

where $W$ - the radial width of the ring. Consequently, there must be a differential precession because the inner edge of the ring precess faster than external. Ring erosion of the characteristic time $\frac{2 \pi}{|\delta \dot{\varpi}|}$, that in our calculations is $1660_{-146}^{+151}$ days for $\mathrm{C} 1 \mathrm{R}$ and $2760_{-67}^{+68}$ days for C2R.

\section{SHEPHERD SATELLITE}

The discovery of narrow rings of Uranus gave impetus to the development of the theory of the ring holding, contrary to the collision of the particles, the Poynting-Robertson effect and differential precession. The presence of shepherd satellites was more plausible explanation for the stability of narrow rings. It has been suggested [3] that the narrow ring is supported by a companion.

We assume that the gap in the rings formed by the satellite of asteroid system is similar to how the Pan satellite forms the Encke gap in A ring of Saturn. Using equation (3), derived from the expression for the sphere of influence, estimate the mass of the satellite shepherd:

$$
m_{S t}=\frac{R^{5 / 2} M_{A}}{a_{S t}^{5 / 2}} \approx(3.27 \pm 0.19) \cdot 10^{15} \mathrm{~kg},
$$

where $R$ - sphere of influence radius $(7100 \pm 100 \mathrm{~m})$ [5] of shepherd satellite. Mass $\left(M_{A}\right)$ of the asteroid (10199) Chariklo calculated using the formula:

$$
M_{A}=\frac{4}{3} \pi a b^{2} \rho \approx 7,82 \cdot 10^{19} \mathrm{~kg}
$$

where $a$ - semi-major axis of the ellipsoid of the asteroid (289800 $\mathrm{m}$ [2]), $b-$ minor axis of the ellipsoid

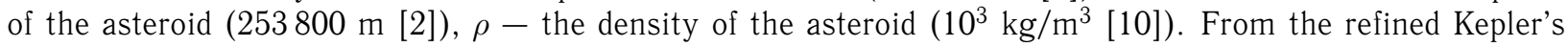
law we find the rotation period $(P)$ shepherd satellites around the main component of the asteroid system:

$$
P=\frac{2 \pi a_{S t}^{3 / 2}}{\sqrt{G\left(M_{A}+m_{S t}\right)}} \approx 6.12_{-0.01}^{+0.23} \text { hours, }
$$

where $G=(6,6740 \pm 0,00031) \cdot 10^{-11} \mathrm{~m}^{3} \cdot \mathrm{s}^{-2} \cdot \mathrm{kg}^{-1}-$ gravitational constant.

The orbital period of the system's main component around its axis is 7.004 hours [7]. Comparing this value with the resulting orbital period of alleged shepherd satellite can be seen that the system approaches to the synchronous rotation [3].

Orbital periods of $\mathrm{C} 1 \mathrm{R}$ and $\mathrm{C} 2 \mathrm{R}$ rings are known and are equal to 0.74 days and 0.78 days, respectively [10]. Ring are approaching to the orbital-orbital resonance 3:1 with shepherd satellite.

\section{CONCLUSIONS}

Considered in this work the phenomenon of erosion asteroid rings (10199) Chariklo, due to the differential effect of precession.

An estimate of the mass and orbital period of the satellite the alleged shepherd supporting the form of rings asteroid system.

Is shown existence of resonances between the spin of the central asteroid of the system, the orbital periods of the rings and the intended shepherd satellite. 
1. Berard D., Sicard B., et al. // American Astronomical Society. - 2015. - 47. - P.104.02

2. Braga-Ribas F., et al. A ring system detected around the Centaur (10199) Chariklo // Nature. - 2014. - 508. P.72-75

3. Murray C.D., Dermot S. Solar System dynamics. - Cambridge, 2010.

4. Fornasier S., et al. TNOs are cool: A survey of the trans-Neptunian region. VIII. Combined Herschel PACS and SPIRE observations of 9 bright targets at 70-500 um // Astron. and Astrophys. - 2013. - 555. - P.A15.

5. Seefelder W., 2002, Lunar Transfer Orbits Utilizing Solar Perturbations and Ballistic Capture, Herbert Utz Verlag, Issenschaft Munchen.

6. Troianskyi V.V. Effect of Non-Sphericity of Gravitational Field of the Asteroid on the its Satellites Orbits Evolution // Odessa Astronomical Publications. - 2015. - 28, Issue 2. - P.299-303.

7. Warner B.D., Harris A.W., Pravec P. Asteroid Lightcurve Data Base. - 2014. http://www.minorplanet.info/lightcurvedatabase.html

8. Winter O., Araujo R., Sfair R. IAU General Assembly, 2015, 29, 2251028.

9. http://www.jpl.nasa.gov

10. http://www.johnstonsarchive.net/astro/astmoons/am-10199.html

Received 22.10.2016

Accepted 4.11.2016 